\title{
РЕЖИСЕРСЬКО-ТВОРЧА СПЕЦИФІКА ДИТЯЧОГО ЕСТРАДНОГО ТЕАТРУ «ЗІРКОВИЙ ЧАС»
}

\author{
Микола Крипчук ${ }^{1 a}$, Дмитро Умлєв ${ }^{2 b}$ \\ ${ }^{1}$ кандидат мистецтвознавства; e-mail: kripchuk@gmail.com; ORCID: 0000-0002-1255-7135 \\ 2 магістр; e-mail: Dimi777umlev@gmail.com; ORCID: 0000-0002-4688-8418 \\ а Київський національний університет культури і мистецтв, Київ, Україна

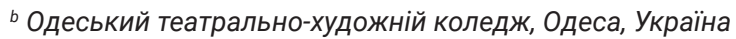

\section{Анотація}

Мета дослідження полягає в науково-теоретичному обґрунтуванні художніх особливостей дитячого естрадного театру, виявленні специфіки режисерських практик у таких колективах, характеристиці змісту, форм і методів роботи на прикладі діяльності дитячого естрадного театру «Зірковий час» М. Одеси. Методологія дослідження базується на використанні таких наукових підходів: комплексного - для розкриття сутності всіх аспектів художньої специфіки дитячого театру; культурологічного - для зіставлення та порівняння філософських, історичних, психолого-педагогічних та мистецтвознавчих складових у діяльності дитячого естрадного театру; емпіричного - для спостереження, інтерв'ювання дітей та батьків тощо. Наукова новизна. Уперше з метою науково-дослідного осмислення зібрано, систематизовано та проаналізовано досвід творчо-організаційної діяльності дитячого естрадного театру «Зірковий час» м. Одеси, схарактеризовано основні режисерські прийоми в роботі з дітьми й узагальнено напрями подальшого розвитку колективу. Висновки. Театр як засіб формування особистості займає одне з перших місць серед інших видів дитячої творчості, він $є$ для дітей джерелом інформації про навколишній світ і закони життя, примушує замислюватися над сенсом людського існування та глибинами людської душі, тому дитячий естрадний театр «Зірковий час» м. Одеси подає теоретичну модель дитячого естрадного театру, що складається з двох напрямів діяльності колективу. Перший передбачає аналіз та визначення особливостей роботи з учасниками вистави, а також дотримання у своїй діяльності певних принципів. Другий напрям стосується безпосередньо творчої діяльності дитячого естрадного театру, зокрема методів, форм і засобів. У статті схарактеризовано сучасні режисерські прийоми та визначено особливості професійної діяльності режисера, який працює в дитячому колективі, що полягають у вкрай обережному ставленні до дитячої театральної творчості з урахуванням вікових, фізіологічних, психологічних властивостей дітей, необхідності створення такої організації театральної творчості дітей, що забезпечить повне самовиявлення юних акторів, зберігаючи подібність до природної дитячої гри; проаналізовано основні режисерсько-творчі технології, а також подальші перспективи розвитку дитячого театру.

Ключові слова: режисерська діяльність; театр «Зірковий час» м. Одеси; дитячий естрадний театр 


\section{Постановка проблеми}

Проблема залучення дітей до театрального мистецтва не є новою для наукових досліджень суміжних з театрознавством галузей гуманітарних знань, зокрема педагогіки, психології. Проте в мистецтвознавчій науці приділено недостатню увагу їі розв'язанню. Це пов'язано з відсутністю у фахівців, які займаються дослідженням цих питань, необхідних спеціальних знань, що дали б змогу ефективно організувати діяльність дітей у цьому напрямі.

Чимало сучасних режисерів, керуючись принципами театральної школи, яку вони сповідують, гуманістичною мораллю класичної літератури і власною інтуїцією, створюють своєрідні етичні та методичні системи, які досить успішно працюють, утім у наявній науковій спадщині не зафіксовано комплексного дослідження цілісної моделі режисерсько-творчої діяльності дитячого естрадного театру, що й обумовило вибір теми.

\section{Аналіз останніх досліджень і публікацій}

Відповідно до мети дослідження проведено вивчення й аналіз науковотеоретичної бази, яку становлять наукові праці (монографії, статті) у періодичних виданнях, що пов'язані з темою роботи. Це праці з естетики, культурології, психології, театрознавства, соціології, філософії та інших споріднених наук. Слід зазначити, що погляди на дитячу театральну творчість і її особливості час від часу змінювалися.

Про початок історії дитячого театру наведено у працях відомих діячів театрального мистецтва Б. С. Глаголіна (1906), М. О. Попова (1910), які сприяли зростанню інтересу до феномену гри та її ролі в психологічному розвиткові дитини (Виготський, 2001; Ельконін, 1999).

Упродовж років дитячу театральну творчість розглядали як засіб естетичного виховання й емоційного розвитку дитини (Єршова, 1991; Нікітіна, 2002), як чинник, що впливає на розвиток її моральних якостей, і метод прищеплення патріотичних почуттів (Апаріна, 2017; Шахрай, 2003).

Багато науковців визначають важливу роль театрального мистецтва в життєдіяльності суспільства й окремої особистості, підкреслюють соціально-регулятивне призначення театру, указують на виконання театром функції соціального інституту, що покликаний гармонізувати життя людини (Арбузов, 1989; Табаков, 2000).

Щодо погляду на театральну діяльність дітей з боку мистецтвознавчого осмислення, то це питання висвітлено недостатньо. Можна навести лише окремі дослідження, зокрема дисертацію А. Б. Нікітіна (2002), де розглядаються психологічні особливості діяльності дітей, їх світоглядне значення у становленні особистісних рис характеру її суб'єктів. В окремих статтях та матеріалах науково-практичних конференцій висвітлено особливості дитячих театрів як універсальної образотворчої моделі формування особистості (В. Д. Зімін (2003), Н. А. Апаріна (2017)), соціально-інноваційну технологію, яка є ефективною у вихованні підлітків (Є. В. Чікатуєва (2013)). 
Усе це підкреслює очевидну необхідність наукового вивчення художніх особливостей дитячої театральної творчості як одного з повноцінних компонентів сучасного театрального мистецтва, які за сучасних умов виводять його за психологопедагогічні межі. У зв'язку з цим необхідно сформулювати мету статті таким чином: на прикладі діяльності дитячого естрадного театру «Зірковий час» схарактеризувати специфіку режисерської практики в таких колективах. Актуальність постановки мети обумовлена також тим, що такі практики в наукових дослідженнях висвітлено на рівні загальних дискусій про їхню роль у постановках з участю дітей.

\section{Виклад основного матеріалу}

Глобальне поширення мас-медіа, нові тенденції розвитку інформаційного суспільства активно та не завжди позитивно впливають на формування естетичних цінностей, поглядів і вчинків дитини, нерідко шкодять здоров'ю та заважають нормальному розвиткові особистості. У таких умовах зростає роль роками виправданих форм духовного розвитку молодого покоління, однією з яких $€$ театр.

Звідси й постає проблема залучення дітей до театрального мистецтва, яке формується на ґрунті багатовікових традицій і за допомогою особливих художніх засобів сприяє процесу індивідуального самовираження дитини.

Місія театру, де грають діти, надзвичайно багатогранна. Крім творчої складової, це ще й унікальна комунікативна система, і середовище формування колективу, де діти вчаться спілкуванню та співтворчості, і місце, де вирішуються складні завдання морального виховання.

У театрі дітей, як і у театрі дорослих, увесь художній процес та етичні відносини в колективі визначаються особистістю лідера-режисера. Від його професійного вміння, почуття часу, знання специфіки дитячої творчості безпосередньо залежать успіх і художній рівень театру.

У дитячому театрі справжній режисер - це не тільки кваліфікований фахівець, а й професійний актор і вихователь. Саме тому кожен, хто працює з дітьми, має пам'ятати, що його завданням та обов'язком $€$ постійна робота над удосконаленням своїх режисерських умінь і самовдосконаленням.

Авторсько-режисерська група дитячого естрадного театру «Зірковий час» робить усе, щоб дітям було цікаво вчитися. А для цього потрібно враховувати особливості роботи з учасниками вистави.

По-перше, слід завжди пам'ятати, що провідні форми психологічної діяльності дітей - гра та спілкування. Отже, кожне навчальне завдання та його розв'язання має передбачати не тільки конкретний творчий результат, а й бути сприйнятим як глядачами, так і учасниками театральної вистави.

По-друге, за умови збереження цілісності задуму заняття слід будувати змінюючи види діяльності, темпоритми та інтенсивність роботи й водночас забезпечувати умови для цілісного особистісного включення дитини у сценічну дію, щоб органічно працювали тіло, почуття, інтелект. 
По-третє, творчі завдання необхідно відбирати та будувати так, щоб вони були особистісно-значущі для всіх учасників процесу (як дітей, так і режисера). Педагогрежисер виступає виключно гравцем, партнером, але не носієм істини.

По-четверте, навіть мінімальні успіхи публічно фіксуються, невдачі обговорюються в робочому порядку, проте завжди ці процедури мають ігровий характер.

Режисери театру уважно, толерантно, тактовно, педагогічно обмірковано заохочують учнів, створюють рівні умови для прояву артистичних здібностей у кожної дитини, опосередковано використовуючи традиційні режисерські технології. Специфічною особливістю режисерської роботи з дитячим театральним колективом $€$ збереження загальної атмосфери творчого процесу, який обов'язково має бути радісним для його учасників, тому слід орієнтуватися для досягнення цієї мети на закони дитячої гри, які не дають зруйнувати тонку межу між фантазією дитини та її реальним світовідчуттям. Отож, так важливо встановити загальні правила ігрових дій для всіх членів колективу та сприяти тому, щоб вони усвідомлювалися як щось особливе, як об'єднавче начало водночас.

У накресленій парадигмі режисери театру «Зірковий час» у своїй діяльності дотримуються таких принципів:

- принципу демократії, який передбачає добровільну участь дитини в обраній діяльності, колективне обговорення творчих проєктів;

- принципу динаміки, що надає дитині можливості активного пошуку свого місця у спільному творчому процесі, постійного розвитку своїх здібностей;

- принципу доступності, який дає змогу працювати з дітьми різного віку, з урахуванням рівня їх вікових та індивідуальних можливостей без фізичних і моральних перевантажень;

- принципу наочності - застосування в процесі навчання та практичної діяльності різноманітної інформації, відеозаписів, музичного матеріалу тощо;

- принципу систематичності та послідовності як у проведенні занять, так і в самостійній роботі, що дає змогу за коротший строк домогтися більших результатів;

- принципу успіху, що веде до формування позитивної «Я-концепції», усвідомлення себе творчою особистістю.

Специфічна особливість дитячого театру полягає і в тому, що діти зростають, залишають театр, а на зміну приходять нові майбутні юні актори. Найперше завдання режисера із самого початку створити в колективі атмосферу творчості, доброзичливості та щирості щодо новеньких; сформувати відчуття єдиної команди. Діти повинні засвоїти необхідні правила та норми поведінки, основи професійної етики; здобути навички самостійної роботи. Тут провідними принципами мають стати гранична самостійність і відповідальність за все, що зроблено на сцені та в житті. Як підкреслював А. В. Ефрос (2000, с.93), спираючись на власний досвід, діти мають зрозуміти, що професіоналізм - не тільки в досконалому прояві своїх акторських здібностей, це ще й уміння чути режисера і відчувати логіку партнера, це виховання в собі особливого слуху до внутрішнього. Не заперечуючи імпровізаційність як головну цінність дитячої вистави, треба не забувати, що вистава повинна мати жорсткий каркас, який би дисциплінував акторів і змушував їх працювати відповідно до режисерського задуму, ходу сценічної дії. 
Режисура вистави в дитячому театрі вимагає свободи пошуку, сприяє розвитку ігрового інстинкту. Тут спектакль не ставлять, його складають, придумують разом з акторами - він з'являється непомітно з ігор і етюдів. Навіть якщо режисер уже має на увазі окрему п'єсу, яку він вважає прийнятною до постановки, іï необхідно обговорювати з дітьми, щоб осмислити певну мету майбутньої вистави, її ідею, враховуючи вікові особливості дітей. Проникнення в структуру запропонованого матеріалу дає змогу дітям на рівні особистого розуміння, а не копіювання чи формального наслідування виразити своє розуміння засобами театральної мови (голосом, пластикою, мімікою та ін.). Вистава має усвідомлюватися як колективна творчість, спільна справа, успіх якої залежить від злагодженості дій усіх учасників, їх взаємодопомоги та взаємовиручки.

Керівники колективу намагаються постійно підтримувати в дітях живий інтерес до театру. Якщо загальний інтерес до мистецтва об'єднує актора й режисера - це одночасно активізує внутрішній інтерес до творчої діяльності.

Театральні форми роботи режисера з дітьми звернені і до почуттів дитини, і до м'язової пам'яті, і до глибин підсвідомості. У процесі творчої діяльності дитина відкриває в собі нові якості. Якщо навчити її довіряти собі, керувати своїми емоціями, спонукати до дій, які вимагають нових відчуттів, незвичних її особистому досвіду, то це обов'язково дасть нагоду дитині придбати нові спроможності. Тільки якщо в основі творчого процесу лежить процес пізнання, духовне осягнення світу на чуттєво-емоційному рівні - можна розраховувати на високі досягнення та справжні відкриття, що дадуть новий художній результат.

Під час навчання дуже важливо правильно використовувати мистецтво образного перевтілення. Дорослі практично завжди виступають у двоєдиному образі - власного статусу і рольової маски. Таке розуміння рольових персональних взаємодій ґрунтується на відомому з античних часів уявленні про життя людського суспільства як про безперервно тривале видовище, в якому людина підвладна силі неземній, і в якому всі без винятку мають свої різноманітні ролі.

Діти є природженими акторами, оскільки здатність грати ролі інших людей допомагає їм краще пристосуватися до навколишнього світу. Щиросердність, гранична віра в запропоновані обставини, невимушене ставлення до умовності гри - усе це притаманне дітям від природи. Завдання режисера полягає лише в тому, щоб перенести все це без втрат на сцену. І ніякої особливої методики тут не існує. Кожний режисер в кожному окремому випадку покладається на своє чуття, на своє вміння грати з дітьми, збережене з власних дитячих років.

На першому етапі роботи з юним актором треба домогтися лише того, щоб дитина нікого не наслідувала, залишалася собою. Відкрити своє «я»- означає відкрити свою органіку, уяву, відчути живий інтерес до процесу, що відбувається на сцені, учасником якого сам незабаром станеш.

На цьому етапі за допомогою спеціальних вправ режисери допомагають дитині позбутися зовнішніх (м'язових) і внутрішніх (психологічних, інтелектуальних) затисків, намагаються повернути їі до себе - природної, справжньої, вільної.

Вправи на розвиток уваги допомагають дітям спостерігати за людьми, жит- 
тєвими ситуаціями та подіями, сприймати мову спілкування (як вербальну, так і невербальну), реагувати на людські вчинки.

Вправи на розвиток уяви сприяють умінню проєктувати життєві ситуації, уявляти варіанти розвитку подій, здійснювати пошук оптимальних рішень.

Вправи на м'язове розслаблення створюють відчуття свободи, упевненості, розкутості, що є дуже важливим для повноцінного спілкування.

Необхідною під час підготовки спектаклів $є$ робота над сценічною мовою, яка розширює лексичний запас, покращує вимову, допомагає в осмисленні тексту. Водночас розвиваються увага, дисциплінованість, витримка та інші риси, необхідні для гармонійної життєдіяльності в колективі. Як зауважив О. П. Табаков (2000, с.227), говорячи про театральну педагогіку: «Це шлях до себе, вміння натискувати на клавіші душі. Тільки треба знати, де вони знаходяться, і створити для цього необхідні умови».

К. С. Станіславський $(2007$, с.222) пояснював, що «репетиція - це не урок за “системою” в школі театру, це процес втілення ідей і думок автора в живі, дієві людські образи».

М. М. Горчаков (1962, с.222), учень і дослідник методу К. С. Станіславського, у посібнику «Робота керівника театрального колективу з виконавцями» наводить основні принципи щоденної роботи режисера. Він розглядає можливість навчання актора не тільки в момент студійних занять, а й у живому репетиційному процесі підготовки спектаклю від епізоду до епізоду, від сцени до сцени, з урахуванням опрацювання та поступового освоєння елементів «системи». У роботі з дітьми тривалі попередні розмови малоефективні, оскільки постає інше завдання освоєння технології акторської професії під час роботи над роллю. Саморозвиток ролі й актора відбувається одночасно, а в театрі, де грають діти, це є неодмінною умовою.

Робота над роллю охоплює декілька етапів. Підготовчий - коли ведеться пошук характеру, «зерна образу», визначення конфлікту, подій, з'ясування мотивів вчинків героя. Діти вигадують біографію свого героя, малюють його портрет. На наступному етапі, коли вже багато відомо про героя, йде процес присвоєння його вчинків, слів; виникає необхідність діяти від його імені. На останньому етапі відбувається ототожнення свого та вигаданого, виправдання вчинків героя. Актор розуміє його логіку, а отже, може спробувати втілити художній образ на сцені.

Важливим для режисера і юних акторів є спільний пошук мізансцен - найкращого сценічного розміщення дійових осіб, що передає їхній стан, розкриває прихований внутрішній світ.

Вагомим складником театральної творчості юних акторів $є$ показ спектаклю перед глядацькою аудиторією. Він не тільки демонструє виконавські вміння юних акторів, а й набуття дітьми вольових якостей, зокрема впевненості, уміння володіти собою перед глядачами.

Так виникла ідея спектаклю «Давайте створимо оперу», де всі дитячі ролі грають діти відповідного віку. Жанр його, тобто умова існування в ньому акторів і глядачів, визначений як розвага для дітей і дорослих. Спектакль складається 
з двох частин. У першій виходять на порожню сцену актори та пропонують самим скласти і розіграти оперу. На сцену з глядацької зали викликають усіх охочих допомогти їм у цьому. Разом приблизно з двадцятьма дітьми - учасниками вистави на сцену виходять і багато дітей-глядачів. Під час таких загальних зборів вирішують написати та зіграти оперу на сюжет про маленького сажотруса, тут же розподіляють ролі авторів і виконавців, починають репетиції окремих номерів. Другий акт вистави - безпосереднє виконання створеної в першому акті опери. Непрофесіоналізм виконавців дитячих ролей підкреслює враження імпровізації. Насправді з'ясовується, що діти з легкістю можуть впоратися з важкою партитурою. Усі діти-глядачі беруть до того ж участь у художньому оформленні майбутньої вистави. В антракті, використовуючи кольорові олівці, займаються підготовкою ілюстрацій на тему опери та прикріплюють їх на імпровізовану завісу. Під час опери в супроводі оркестру діти-глядачі виконують хорові партії досить непростих музичних номерів. Зі звичайних глядачів вони перетворюються в учасників вистави-гри. Якщо врахувати, що майданчик театру не обмежується сценічними підмостками й охоплює всю глядацьку залу, проходи між крісел, оркестрову яму, то залучення в гру інших глядачів неминуче. I не тільки дітей, а й дорослих. Вони теж грають з дітьми, інакше театр-гра відбутися не може.

Авторсько-режисерська група театру обережно ставиться до вибору репертуару. Проте під час створення п'єси за мотивами вже наявної казки, повісті, оповідання треба, щоб постановників не підвели художній смак, тактовне ставлення до авторів творів, за якими здійснено інсценізації.

Звичайно, казка як драматичний матеріал більш умовна, близька та зрозуміла дітям за змістом; надає широкі можливості для творчого прояву всіх учасників вистави; щиро сприймається глядачами всіх вікових категорій. Казка, як і класика, ніколи не підведе. Г. О. Товстоногов (1984, с.113) вважав, що цінність класичного твору вічна, і вона не тільки в пізнавальному значенні, а й у тій величезній естетичній силі та здатності морально впливати на уми і душі сучасників. «Треба змусити минуле служити сьогоднішнім завданням», - стверджував він і закликав грати класиків.

Різноманітні вистави, в яких розкривається діалектика добра і зла, краще підготують дітей до серйозних розмов у театрі, до майбутніх подій у житті. Примітивне зло і підсолоджене добро не прийнятні в театрі. Діти й дорослі однаково відчувають і цінують тільки справжнє, тому що не буває в людей різновікового ставлення до вічних цінностей. А режисери повинні знайти такі слова, щоб просто і ясно пояснювати юним акторам, юним глядачам зовсім не прості речі.

У репертуарі театру «Зірковий час», крім мюзиклів на казкові сюжети, є і оригінальні вистави, створені з урахуванням можливостей дітей-акторів та уподобань дітей-глядачів. Це вистави про нові загадкові, веселі та непередбачувані пригоди барона Мюнхгаузена («Як обманути комп'ютерний вірус» і «Подорож на Місяць»). Юні актори театру відтворюють на сцені не трафаретні чорно-білі образи, а виразні характери. Тут немає однозначно поганих чи хороших героїв - у різних ситуаціях вони виявляють ті чи інші риси своїх характерів, залишаючи глядачу можливість робити власні висновки. 
Дитячий театр, безумовно, поступається новітнім технологіям у відтворенні на сцені казкового чуда та продовжує користуватися старим, випробуваним арсеналом (акторами, режисурою, сценографією, музичним рядом) і вкотре поєднувати все це для створення власного казкового світу. Проте необхідність частої зміни репертуару, створення спектаклів в умовах обмеженого фінансування призводить до тиражування елементів сценографії, одноманітного використання оформлення вистав, колажування типових зображень, тобто до всього того, що негативно впливає на якість вистави.

Точне і вдале поєднання всіх цих добре відомих театральних засобів досить успішно спрацьовує в багатьох випадках.

Театр - це мистецтво, яке є відображенням душі, думок, ідей. Діти - це театральна інтерпретація дійсності, яка перебуває на межі вигадки і реальності. Через сценічні форми діти можуть відкрито заявити про свої проблеми та бажання і цим привернути до себе увагу дорослих.

Але подальший розвиток сучасного дитячого театру неможливий без застосування нових віртуальних технологій. За ними майбутнє театру, і відкидати їх можливості не варто.

Використання нових технологій у постановочному процесі розширює творчі можливості режисерів і сценографів у створенні художнього образу вистави, що відповідає новим естетичним вимогам часу.

Сучасні діти-глядачі існують в інформаційному просторі, який давно вже насичений новітніми технологіями, тому для багатьох з них відсутність таких інновацій у театрі не бажана і не зрозуміла. Але впровадження нового має проходити обережно. Неприпустимо, щоб видовищність затьмарювала режисерський задум. Передбачуваність, стандартність, одноманітність рішень, використання мінімального набору засобів (звуку, світла, відеоряду, спецефектів) не сприяє формуванню художнього смаку глядачів так само, як і велика кількість мультимедійних трюків відволікає від змісту вистави.

Наукова новизна. Уперше з метою науково-дослідного осмислення зібрано, систематизовано та проаналізовано досвід творчо-організаційної діяльності дитячого естрадного театру «Зірковий час» м. Одеси, схарактеризовано основні режисерські прийоми в роботі з дітьми й узагальнено напрями подальшого розвитку колективу.

\section{Висновки}

Отже, зважаючи на ігрову природу театрального мистецтва і притаманного дітям «драматичного інстинкту», діяльність дитячого театру не заперечує використання традиційних сценічних форм. Проте в них слід передбачати більш широке застосування елементів синтетичної природи, які б посилювали контакти гри артистів з глядацькою залою. Ці елементи як основа дитячої активності трансформуються в рушійну силу розвитку сценарію та дають змогу глядачу перетворюватися зі спостерігача подій у співтворця, спроможного не тільки брати в них участь, а й впливати на їх розвиток, створювати доброзич- 
ливу атмосферу, яка б налаштовувала дітей на позитивне сприйняття вистави як свята.

Досвід діяльності колективу «Зірковий час» м. Одеси доводить, що в сучасному дитячому театрі можемо використовувати інноваційні методи роботи. Як універсальна форма, що містить різні виразні елементи (музику, пісні, танці, захопливий сюжет), дає змогу більш органічно залучати дітей до театрального мистецтва у всіх його жанрових проявах.

\section{СПИСОК ПОСИЛАНЬ}

Арбузов, К.М., 1989. Искусство служения детству. Театр, 12, с.165-170.

Выготский, Л.С., 2001. Игра и ее роль в психическом развитии ребенка. В: Психология развития. Санкт-Петербург: Питер.

Глаголин, Б.С., 1906. Несколько слов о детском театре. 2-е изд. Саратов: Типо-литография П.С. Феокритова.

Горчаков, Н.М., 1962. Режиссерские уроки Станиславского. Беседы и записи репетиций. Москва: Искусство.

Григорьева, О.И. и Чикатуева, Е.В., 2014. Детский мюзикл как социально-инновационная технология качества образования в современной начальной школе. В: Л.И. Клочковой и А.А.Белова, ред. Диверсификация механизмов развития креативной среды общеобразовательной организации в целях инновационного развития системы школьной социализации обучающихся: материалы Московской городской научно-практической конференции с международным участием. Москва. Россия, 27 марта 2014. Москва.

Ершова, А.П., 1991. Искусство в жизни детей. Москва: Просвещение.

Зимин, В.Д., 2003. Театр детей как новая форма культурно-творческого процесса. В: Культура. Искусство. Образование: материалы международной научно-практической конференции. Смоленск, Россия, 28 января 2003. Смоленск: Смоленский государственный институт искусств, с.210-215.

Лесина, Т.Е. сост., 2002. Детский театр - это серьезно! Санкт-Петербург: Санкт-Петербургский городской Дворец творчества юных.

Немирович-Данченко, В.И., 1952. Театральное наследие. Москва: Искусство. Т. 1.

Немирович-Данченко, В.И., 1989. Рождение театра: воспоминания, статьи, заметки, письма. Москва: Правда.

Никитина, А.Б., 2001. Театр, где играют дети. Москва: ВЛАДОС.

Никитина, А.Б., 2002. Театр, где играют дети, в поисках собственной идентичности. Кандидат наук.

Опарина, Н.А., 2017. Театр - универсальная образовательная модель. Наука и школа, 6, с.107-111. Попов, Н.А., 1910. Детский театр или театр для детей? Рампа и жизнь, 48.

Станиславский, К.С. и Чехов, М.А., 2007. Работа актера над собой. О технике актера. Москва: Артист. Режиссер. Театр.

Сундукова, В.Н., 1966. Воспитание художественной индивидуальности актера в театральной школе. Автореферат кандидата искусствоведения.

Табаков, О.П., 2000. Моя настоящая жизнь: Автобиографическая проза. Москва: ЭКСМО-Пресс. Товстоногов, Г.А., 1984. Зеркало сцены. В: Т. 1. О профессии режиссера. Москва: Искусство. 
Топорков, В.О., 1961. Про техніку актора. Київ: Державне видавництво образотворчого мистецтва і музичної літератури УРСР.

Шахрай, В.М., 2003. Формування ціннісних орієнтацій підлітків у діяльності дитячого театру. Кандидат наук.

Шульпин, А.П., 2004. Театр, где играют дети и взрослые. В: А.П. Шульпин, сост. Театральные каникулы. Москва: ГРДНТ.

Эльконин, Д.Б., 1999. Психология игры. 2-е изд. Москва: ВЛАДОС.

Эфрос, А.В., 2000. Профессия: режиссер. Москва: Вагриус.

\section{REFERENCES}

Arbuzov, K.M., 1989. Iskusstvo sluzheniia detstvu [The art of serving childhood]. Teatr, 12, pp.165-170.

Efros, A.B., 2000. Professiia: rezhisser [Profession: Director]. Moscow: Vagrius.

Elkonin, D.B., 1999. Psikhologiia igry [The psychology of the game]. 2nd ed. Moscow: VLADOS.

Ershova, A.P., 1991. Iskusstvo v zhizni detei [Art in the life of children]. Moscow: Prosveshchenie. Glagolin, B.S., 1906. Neskolko slov o detskom teatre [A few words about the children's theater]. 2nd ed. Saratov: Tipo-litografiia P.S. Feokritova.

Gorchakov, N.M., 1962. Rezhisserskie uroki Stanislavskogo. Besedy i zapisi repetitcii [Directorial lessons of Stanislavsky. Conversations and rehearsal recordings]. Moscow: Iskusstvo.

Grigoreva, O.I. and Chikatueva, E.V., 2014. Detskii miuzikl kak sotcialno-innovatcionnaia tekhnologiia kachestva obrazovaniia v sovremennoi nachalnoi shkole [Children's musical as a social and innovative technology for the quality of education in a modern elementary school]. In: L.I. Klochkovoi and A.A. Belova, eds. Diversifikatciia mekhanizmov razvitiia kreativnoi sredy obshcheobrazovatelnoi organizatcii $v$ tceliakh innovatcionnogo razvitiia sistemy shkolnoi sotcializatcii obuchaiushchikhsia [Diversification of the development mechanisms of the creative environment of a general educational organization for the innovative development of the school socialization system for students] materials of the Moscow City Scientific and Practical Conference with international participation. Moscow. Russia, 27 March 2014. Moscow.

Lesina, T.E. comp., 2002. Detskii teatr - eto serezno! [Children's Theater. This is serious!] St. Petersburg: Sankt-Peterburgskii gorodskoi Dvoretc tvorchestva iunykh.

Nemirovich-Danchenko, V.I., 1952. Teatralnoe nasledie [Theatrical heritage]. Moscow: Iskusstvo. Vol. 1.

Nemirovich-Danchenko, V.I., 1989. Rozhdenie teatra: vospominaniia, stati, zametki, pisma [The birth of the theater: memoirs, articles, notes, letters]. Moscow: Pravda.

Nikitina, A.B., 2001. Teatr, gde igraiut deti [Theater, where children play]. Moscow: VLADOS.

Nikitina, A.B., 2002. Teatr, gde igraiut deti, v poiskakh sobstvennoi identichnosti [Theater, where children play, in search of their own identity]. Ph.D.

Oparina, N.A., 2017. Teatr - universalnaia obrazovatelnaia model [Theater is a universal educational model]. Nauka i shkola, 6, pp.107-111.

Popov, N.A., 1910. Detskii teatr ili teatr dlia detei? [Children's theater or theater for children?] Rampa i zhizn, 48.

Shakhrai, V.M., 2003. Formuvannia tsinnisnykh oriientatsii pidlitkiv u diialnosti dytiachoho teatru [Formulation of the official ornate at the children's theater]. PhD. 
Shulpin, A.P., 2004. Teatr, gde igraiut deti i vzroslye [Theater, where children and adults play]. In: A.P. Shulpin, comp. Teatralnye kanikuly. Moscow: GRDNT.

Stanislavskii, K.S. and Chekhov, M.A., 2007. Rabota aktera nad soboi. O tekhnike aktera [The actor's work on himself. On the technique of the actor]. Moscow: Artist. Rezhisser. Teatr.

Sundukova, V.N., 1966. Vospitanie khudozhestvennoi individualnosti aktera $v$ teatralnoi shkole [Education of the actor's artistic personality in a theater school]. Abstract of a candidate of art history.

Tabakov, O.P., 2000. Moia nastoiashchaia zhizn: Avtobiograficheskaia proza [My real life: Autobiographical prose]. Moscow: EKSMO-Press.

Toporkov, V.O., 1961. Pro tekhniku aktora [About the actor technique]. Kyiv: Derzhavne vydavnytstvo obrazotvorchoho mystetstva i muzychnoi literatury URSR.

Tovstonogov, G.A., 1984. Zerkalo stceny [Mirror scene]. In: Vol. 1. O professii rezhissera [About the profession of director]. Moscow: Iskusstvo.

Vygotskii, L.S., 2001. Igra i ee rol v psikhicheskom razvitii rebenka [The game and its role in the mental development of the child]. In: Psikhologiia razvitiia. Sankt-Peterburg: Piter.

Zimin, V.D., 2003. Teatr detei kak novaia forma kulturno-tvorcheskogo protcessa [Children's Theater as a new form of cultural and creative process]. In: Kultura. Iskusstvo. Obrazovanie: materialy mezhdunarodnoi nauchno-prakticheskoi konferentcii [Culture. Art. Education] materials of the international scientific-practical conference. Smolensk, Russia, 28 January 2003. Smolensk: Smolenskii gosudarstvennyi institut iskusstv, pp.210-215.

\title{
РЕЖИССЕРСКО-ТВОРЧЕСКАЯ СПЕЦИФИКА ДЕТСКОГО ЭСТРАДНОГО ТЕАТРА «ЗВЕЗДНЫЙ ЧАС»
}

\author{
Николай Крипчук ${ }^{1 a}$, Дмитрий Умлев ${ }^{2 b}$ \\ ${ }^{1}$ кандидат искусствоведения; e-mail: kripchuk@gmail.com; ORCID: 0000-0002-1255-7135 \\ ${ }^{2}$ магистр; e-mail: Dimi777umlev@gmail.com; ORCID: 0000-0002-4688-8418 \\ а Киевский национальный университет культуры и искусств, Киев, Украина \\ ' Одесский театрально-художественный колледж, Одесса, Украина
}

\begin{abstract}
Аннотация
Цель исследования заключается в научно-теоретическом обосновании художественных особенностей детского эстрадного театра, выявлении специфики режиссерских практик в таких коллективах, характеристике содержания, форм и методов работы на примере детского эстрадного театра «Звездный час» г. Одессы. Методология исследования предусматривает использование следующих научных подходов: комплексного - для раскрытия сущности всех аспектов художественной специфики детского театра; культурологического - для сопоставления и сравнения философских, исторических, психолого-педагогических и искусствоведческих составляющих в деятельности детского эстрадного театра; эмпирического - для наблюдения, интервьюирования детей и родителей и т. д. Научная новизна. Впервые с целью научно-исследовательского осмысления собран,
\end{abstract}


систематизирован и проанализирован опыт творческо-организационной деятельности детского эстрадного театра «Звездный час» г. Одессы, охарактеризованы основные режиссерские приемы работы с детьми и обобщены направления дальнейшего развития коллектива. Выводы. Театр как средство формирования личности занимает одно из первых мест среди других видов детского творчества, он для детей является источником информации об окружающем мире и законах жизни, заставляет задумываться над смыслом человеческого существования и глубинами человеческой души. Поэтому детским эстрадным театром «Звездный час» г. Одессы предложено теоретическую модель детского эстрадного театра, состоящую из двух направлений деятельности коллектива. Первый предусматривает анализ и определение особенностей работы с участниками спектакля, а также соблюдения в своей деятельности определенных принципов. Второе направление касается непосредственно творческой деятельности детского эстрадного театра, в частности методов, форм и средств. В статье охарактеризованы современные режиссерские приемы и определены особенности профессиональной деятельности режиссера, работающего в детском коллективе, которые заключаются в крайне осторожном отношении к детскому театральному творчеству с учетом возрастных, физиологических, психологических свойств детей, в необходимости создания такой организации театрального творчества детей, которая обеспечит полное самовыражение юных актеров, сохраняя сходство с естественной детской игрой; проанализированы основные режиссерско-творческие технологии, а также дальнейшие перспективы развития детского театра.

Ключевые слова: режиссерская деятельность; театр «Звездный час» г. Одессы, детский эстрадный театр

\title{
DIRECTOR-CREATIVE SPECIFICITY CHILDREN'S VARIETY THEATER "STAR TIME"
}

\author{
Mykola Krypchuk ${ }^{1 a}$, Dmitry Umlev²b \\ ${ }^{1}$ PhD in Art History; e-mail: kripchuk@gmail.com; ORCID: 0000-0002-1255-7135 \\ 2 Master; e-mail: Dimi777umlev@gmail.com; ORCID: 0000-0002-4688-8418 \\ ${ }^{a}$ Kyiv National University of Culture and Arts, Kyiv, Ukraine \\ ${ }^{b}$ Odessa Theater and Art College, Odessa, Ukraine
}

\begin{abstract}
The purpose of the article is to scientifically and theoretically substantiate the artistic features of the children's variety theater, to identify the specifics of directorial practices in such groups, to characterize the content, forms and working methods of the example of the children's star theater "Star time" in Odessa. The research methodology involves the use of the following scientific approaches: integrated is to disclose the essence of all aspects of the artistic specificity of children's theater; cultural is for contrasting and comparing the philosophical, historical, psychological, pedagogical and art components in the activities of children's pop theater; empirical is for observing, interviewing children and parents, etc. Scientific novelty. For the first time, for the research purpose, the experience of creative and organizational activity of the children's variety
\end{abstract}


theater "Star Time" of Odessa was collected, the basic directorial techniques in work with children were characterized and the directions of the collective further development were summarized. Conclusions. Theater as a means of personality formation is one of the first places among other types of children's creativity, it is for children a source of information about the world and the laws of life, and it makes you think about the meaning of human existence and the depths of the human soul. Therefore, the children's pop theater "Star Time" of Odessa proposed a theoretical model of the children's pop theater, consisting of two areas of the collective. The first involves the analysis and determination of the working features with participants in the performance, as well as compliance with certain principles in their activities. The second direction relates directly to the creative activities of children's pop theater, in particular methods, forms and means. The article describes modern directorial techniques and defines the professional activities features of the director working in the children's team, which are extremely cautious about children's theater creativity, taking into account the age, physiological, psychological properties of children, the need to create such an organization of theatrical creativity of children that will ensure full self-expression of young actors, while maintaining a resemblance to a natural children's game; analyzed the main directorial and creative technologies, as well as further prospects for the children's theater development.

Keywords: directing activity; theater "Star time" in Odessa, children's variety theater 